\title{
THE POLITICS OF SCHOOL CHOICE \\ IN TWO COUNTRIES WITH LARGE \\ PRIVATE-DEPENDENT SECTORS (SPAIN AND CHILE): FAMILY STRATEGIES, COLLECTIVE ACTION AND LOBBYING
}

This paper was presented at the seminar organised by the Réseau pour l'Analyse Pluridisciplinaire des Politiques Educatives (RAPPE) in Geneva in 2009. Afterwards, a final, reviewed version was published in this journal:

Rambla, Xavier, Valiente, Óscar and Frías, Carla (2011) 'The politics of school choice in two countries with large private-dependent sectors (Spain and Chile): family strategies, collective action and lobbying', Journal of Education Policy, 26: 3, 431 — 447

\section{RESEARCH ARTICLE}

ABSTRACT. - In many countries choice of school is an increasing concern for families and governments. In Spain and Chile, it is also associated with a long-standing political cleavage on the regulation of large sectors of private-dependent schools. This article analyses both the micro- and the macro-politics of choice in these two countries, where lowstatus 15 year-old students record a significant segregation. At the micro level, some evidence is provided that not only middle-class skilful choosers but also the political representatives of private-dependent schools manage to pursue their interests drawing on economic, social and cultural capital. At the macro level, evidence also shows that the lobbies defending private-dependent schools can use and maintain these power resources. However, in some episodes collective action is an effective power resource for those who campaign in favour of a stricter regulation of these schools, but its influence is much difficult to maintain for longer periods.

In recent decades the debate on school choice has been significant in the UK and the USA, but nowadays it is gaining importance in such diverse countries as Belgium,

Chile, France, India, the Netherlands, New Zealand, Spain and many others.

Furthermore, researchers have observed a widespread use of choice to seek relative, positional advantage regardless of value-driven national traditions of ethnic, pedagogic or religious school pluralism (Butler and Zanten, 2007). This paper wants to contribute to the sociological and political analyses of this issue by exploring the strategies of both families and collective actors. In Spain and Chile most families face the dilemma of enrolling their offspring in either public schools or private-dependent, state-funded schools.

In general, school choice programmes consist of either governments liberalising enrolment (e.g. by funding schools according to parental preferences), compensating for the indirect costs of choice (e.g. making information on local schools available, subsidising transport between localities or neighbourhoods in order to be able to attend 
the school of preference), promoting a differentiated school supply (e.g. by paying for small schools everywhere, by allowing autonomy in curricular and organisational aspects), or mostly, funding private schools (e.g. by delivering vouchers to families, by transferring money to the institution if it meets specific criteria). Thus, three types of schools may often be distinguished on the grounds of differential ownership, funding and management: public schools are run, funded and regulated by (national, regional or local) governments; private-dependent schools are run by private owners or commissioned institutions but funded and regulated by governments; and privateindependent schools are maintained by private owners and funded by tuition fees (Fletcher-Campbell et al, 2007).

Although the topic entered policy studies with convergent interest in quasi-markets, parental involvement and complex governance, the scope of discussion eventually included equity and socio-economic segregation too. In fact, when parents can choose the institution they prefer and educators can select which pupils they admit, the average resulting trend is a socio-economic, ethnic and academic segregation of school intakes (West et al, 2004; Fuchs and Wößmann, 2006; Alegre and Ferrer, 2009). This pattern posits an interesting sociological question on the complex links between microdecisions and macro-politics (Zanten, 2003; Ball, 2008).

In this article we look at school choice in Spain and Chile on the grounds that both countries have experienced a democratic transition in the last few decades, have transformed the regulation of private-dependent schools into a salient political cleavage, and have consolidated a large sector of private- dependent schools (see table 1). This base of commonalities yields a small but significant sample for a comparative analysis of the school-choice strategies deployed by middle- and working-class families and the collective actions launched by the associations in support of each type of school ${ }^{1}$.

\footnotetext{
1 By reading the work of the authors in the context of wider discussions on school choice in these countries, the article relies on comparable qualitative analyses of choice strategies and collective action as well as on quantitative analyses of segregation on each country. In Spain, qualitative studies include samples of interviews and focus groups carried out in Catalonia, Madrid and Castilla-La Mancha since the nineties (Bernal, 2005; Rambla, 2006; Benito and González, 2007; Olmedo and Santa Cruz, 2008). These are complemented by an estimation of the trend of indexes in Catalonia (Valiente and Rambla, 2009) as well as multi-level models based on census (Valiente, 2009) and PISA (Escardíbul and Villarroya, 2009; Alegre and Ferrer, 2009) data. In Chile, qualitative studies include samples of interviews carried out in the last decade (Almonacid, Luzón and Torres, 2008), some of them with families and head-teachers in the areas of Santiago and Rancagua (Frias, 2009) as well as estimation of indexes and multivariate analyses of local segregation patterns (Valenzuela, Belleï, De los Rios, 2008).
} 
The main research questions focus on regulation and social strategies. Significantly, Franco's dictatorship promoted private-dependent educational institutions in Spain from 1939 to 1977, and Pinochet's regime (1973-89) promulgated in 1981 an education reform fostering quasi-markets where municipal and private, subsidised schools were expected to compete. When both countries underwent a democratic transition at the end of authoritarian rule, the new governments tried to regulate these school sectors so as to create a more integrated system. In this context, the interplay of the individual, family strategies, collective action and public policies appears to have produced a tighter regulation in Spain than in Chile.

We draw on some general sociological theories and the rich corpus of sociological research devoted to school choice in order to analyse the web of interests involved in school admissions in the two education systems. Our conclusion is a general and comparative argument on the divides emerging out from family choice practices and schools' selection strategies. 
Table 1: Distribution of primary and lower-secondary students by type of institution (2007)

Public schools $\%$
Private governmentdependent schools $\%$
Private independent schools
Netherlands ${ }^{(1)}$

Belgium

Chile

Australia

Spain

France

Korea

United Kingdom

New Zealand

Denmark

Hungary

Sweden

Austria

$\underline{\text { Slovak Republic }}$

Finland

Czech Republic

Luxembourg

Iceland

Norway

Portugal

Switzerland

Poland

Italy

Canada

Germany

Greece

Ireland

Japan

Mexico

Turkey

United States
31.09

43.83

45.49

71.46

70.32

78.68

83.06

79.96

82.01

87.52

88.34

91.55

91.7

91.99

92.93

94.1

87.12

95.15

95.7

86.88

94.21

95.18

94.28

100

100

93.87

99.19

89.81

88.85

97.9

90.62
68.91

56.17

48.11

28.51

25.18

20.77

16.3

14.79

13.9

12.34

11.66

8.45

8.3

8.01

7.07

5.9

5.18

4.68

4.3

4.25

2.09

0.75

0.37

0

0

0

0

0

0

0

0
0 0

6.4

0.04

4.5

0.56

0.64

5.25

4.09

0.14

0

0

0

0

0

0

7.7

0.17

0

8.88

3.7

4.07

5.35

0

0

6.13

0.81

10.19

11.15

2.1

9.38

Note $^{(1)}$ : NL figures for 2004. 
Source: Author's calculation from OECD (2010)

\section{Politics of school choice}

During the twentieth century some national traditions identified with choice of school whereas others institutionalised uniform catchment areas in order to promote civic values by mixing diverse social groups in the same space (Glenn, 1989). In contrast, nowadays global, state and local collective agents intervene in this policy area so that decision-making currently undergo intricate global, national and subnational processes (Dale, 2005; Robertson, 2005). Thus, they are displaced towards upper political scales to the extent that the OECD (Rizvi and Lingard, 2006) and the World Bank (Bonal, 2002) become interested in programmes that may enhance choice options. A parallel downward movement is observed when schools struggle to select their intake by means of diverse public- private arrangements, and when some families aim at ensuring they have their preferred schools whilst others protest against the consequent social divides (Zanten, 2002; Maroy, 2004, 2006; Maroy and Demailly, 2004; Poupeau, François, Couratier, 2007). However, these changes do not necessarily undermine state capacity but help governments to make their decisions at global, national and local levels according to the political opportunities they perceive.

In recent decades several social changes rendered the politics of school choice more complex in many countries, compared to former schemes simply inspired on very symbolic values of religious and ethnic pluralism, republican uniformity and classbiased excellence. Thus, international lobbying, government policies and urban transformations have contributed to introduce pro-choice schemes in most Anglo-Saxon countries (Ball, 2008) and to cause the demise of the French Republican catchment areas. Despite a strong emphasis on homogeneous procedures of school admission, for several years econometric estimations have discovered rampant indexes of segregation in this country (Benabou, Kramarz, Prost, 2005), mostly due to the middle-class flight from working-class suburbs (Maurin, 2004), deep contradictions that came about when la charte scolaire lost pace with urban transformations (Felouzis, Liot, Perroton, 2004), and changes in the views of 'national' majorities. Recently, 'global' policy 
recommendations were adopted by the incumbent administration after these local, regional and national processes had already provoked important transformations.

A sound academic tradition in sociology understands the interaction between these levels of decision-making as a field wherein agents pursue their aims drawing on their power resources. They are empowered by their own consciousness and a reflexive, partial knowledge of the circumstances (Elias, 1983: 207; Bourdieu, 1986); furthermore, they are also endowed with varying sets of emergent structural properties and emergent cultural properties that are conducive to impinging on the behaviour or the other involved parties (Archer, 2000: 307). For instance, the education of children is a key project for many people who connect their expectations with their own identity, but some parents avail of particular opportunities to get a socially mixed school, and have different margins of manoeuvre to deal with official requirements (i.e. emergent structural properties). Also, some cultural frames either strengthen or weaken certain school-admission procedures (i.e. an emergent cultural property).

\section{Power in the arena of school choice}

Power is at stake when particular social agents manage to influence the others' behaviour (Bourdieu, 1986; Korpi, 1985, 2001; Lukes, 2005). Research findings provide some illustrations of its role in school choice, namely: parents putting pressure on head teachers, middle-class families spreading and making up rumours in order to modulate the esteem of local schools, and governments regulating the types of educational institutions in a given school system (Hatton, 1985; Ball and Vincent, 1998; Ball, 2008).

Power is quite visible when some agents punish those who damage their interests in circumstances of open conflict in which everybody must afford the conflict costs of the involved resources. For example, complaining families may be blamed for inappropriate intervention, middle-class flight requires the outgoing families to pay for alternative housing and the remaining ones to face urban degradation, and coalitions for and against school choice always face a risk of political defeat. In other circumstances social agents disguise conflict by patrolling the political agenda or avoid it by shaping the preferences of other agents. In this way, they save conflict costs but bear the 
mobilisation costs of making these resources available (by enacting political ideologies and collective identities in support of some interests) and the maintenance costs of keeping them on stand-by. In our case, at first sight the available observations of pathdependent effects underpinning pro-choice regulation (Ball, 2008) suggest that the politics of school choice have woven a particular field of activity featured by a 'strategic selectivity' that makes neoliberal positions prevail (Jessop, 2007).

In the arena of school choice parents deploy varied sets of power resources made of particular combinations of personal, structural and cultural emergent properties of social agents (Archer, 2000) They draw on networks (social capital), income and property (economic capital) and the rules of prestige and distinction embodied in academic credentials (cultural capital) in order to pursue their interests (Bourdieu, 1986), thus facing emergent structural distributions which have been fashioned beyond their particular will. Some of them also engage in collective action by joining campaigns, thus establishing links of collaboration and facing conflict with other parental groups as well as with governments, teacher unions, and school-owners bodies. Collective action normally takes place when people remake cultural emergent properties by means of certain ideological frames and particular repertoires of action well-grounded in their political environment. In these moments personal and structural properties also play a role in their capacity for organisation, but the main trigger of collective action is the cultural realisation and definition of political opportunity (Tarrow, 1998; Mundy and Murphy, 2001).

This theoretical framework is quite helpful to relate school-admission filters and segregation. It shows how admission practices may increase segregation by empowering those strategies that cluster the wealthier classes together in the same schools, and disempowering those strategies that could distribute a mixed intake between all the schools. It sensitises researchers to enquire whether, despite some episodes of conflict, political actors can mobilise and/or maintain their (economic, social and cultural) capitals and collective action at an affordable cost. A plausible hypothesis would argue that some political actors may become able to influence so that their children are concentrated in the most prestigious schools. A key sociological conclusion would see these divisions of school choice as a case of social closure in which these agents hoard the better opportunities by closing access to others. The consequence is durable 
inequality rooted in particular social categories that are relevant in several spaces (Tilly, 1998; Therborn, 2006).

Categorical inequality impinges on school choice when selective admission practices raise barriers for particular social groups, who are therefore excluded from better equipped facilities, better trained teachers or appropriate school climates. Whereas in lesser developed countries primary schools produce this effect by charging families, governments by underfunding basic education, and traditional authorities by excluding girls (Tomasevksy, 2006), in more prosperous countries a web of local and national forces sometimes hoards educational opportunities through tracking, grade retention and selective admission, which bias the inter-school distribution of low-achieving students and damage their very academic performance and their own self-image (Dupriez, Dumay, Vause, 2008).

\section{Hoarding educational opportunities through school choice}

British researchers have designed and applied a very helpful typology of family choice strategies drawing on Stephen Ball's work (Ball and Gewirtz, 1995; Ball, 1997; Ball and Vincent, 1998), which has yielded interesting results in the UK (West, 2004), France (Zanten, 2003; Raveaud and Zanten, 2007), Spain (Rambla, 2006; Benito and González, 2007; Olmedo and Santa Cruz, 2008), the US (Lareau, 1995), New Zealand (Thrupp, 2007) and other countries. Narodowski and Nores (2002) and Filgueira and Bogliaccini (2004) also provide some partial examples for Argentina, Chile and Uruguay. By combining educational and urban data, some studies have also unveiled particular critical combinations of housing and schooling strategies that mould local school maps in France (Maurin, 2004) and the US (Reardon, 2008).

The bulk of this research finds that it is skilful, middle-class choosers who seek a good school for their children. As a rule, they are aware of the school ethos, the pedagogic guidelines, the curriculum particularities, the nuances of children's psycho-social development and so on. A few of them sometimes have intense dilemmas between their role as good parents committed to finding any advantage as regards their offspring, and their role as good citizens committed to a school's social heterogeneity as established in mixed comprehensive schools. On the contrary, lower social classes enrol their children 
in the local school regardless of all these implications (Crozier et al, 2008; Vincent, Ball, Braun, 2008). In other words, cultural hierarchies shape school esteem and preferences in the same way that family educational practices and school pedagogies eventually yield restricted and elaborated learning (Bernstein, 1996). Significantly, while middle-classes internalised the official pro-market discourse during the incumbent period of the Conservative party in Britain between 1981 and 1997 (Boulton and Coldron, 1996), researchers also observed that choice reminded working-class parents of painful personal experiences associated with failure (Reay and Ball, 1997).

Besides this complex interplay of differential family educational styles and strategies, several studies have revealed a growing evidence of intentional closure too. In essence, middle-class families avail of social and cultural capital to navigate the local, intricate institutions of school admission, whereas mobilising these power resources is too costly for working-class parents. Thus, in Anglo-Saxon countries middle-class skilful choosers have also proved to be very good at pressurising head teachers, infiltrating scholarship schemes aimed at those who are most in need, using rumours and 'hot' information, and carefully calculating the pros and cons of their options. This point is particularly relevant where quasi-markets were implemented for the sake of equal opportunities and meritocracy (Hatton, 1985; Edwards, Fitz, Whitty, 1989; Ball and Gewirtz, 1995; Lareau, 1995; Ball, 1998; Thrupp, 2007).

With reference to the afore-mentioned, it is plausible to ask whether some families seek selective schools and whether some schools reject 'undesirable' students despite receiving funds to deliver a public service. In Britain the concatenation of reforms and programmes has consolidated an official approach regardless of evidence-based evaluations (Ball, 2008). But further evidence should be necessary in order to spell out the underlying connections between practices at the local and the national scales. At this point, the cases of Spain and Chile may be quite illustrative because of the visibility of private-dependent and public school sectors. The following two sections will focus on these countries so as to portray key reforms in their school-admission regimes and correlative trends in segregation. They also illustrate the probable causal mechanisms that may link choice and segregation through categorical inequality (Tilly, 1998), and the raising of collective action in favour of a stricter regulation of private-dependent schools (Tarrow, 1998). 


\section{Spain: struggling and lobbying}

In Spain, the education system embraces the two big public and private-dependent sectors. One of the main recent institutional changes was the creation of a unique secondary comprehensive, compulsory cycle for 12 to 16-year-olds in the nineties. The central government regulates school admission, funding schemes and the basic curriculum framework, but the seventeen 'autonomous communities' manage the school systems and develop these guidelines according to their own policy.

It is the Socialist administrations who have regulated choice and types of institution. In 1985 the Organic Act on the Right to Education required that private-dependent schools elected councils, signed official agreements (concerts) and implemented co-education in order to be eligible for public subsidies supporting their compulsory primary and secondary programmes. In 2006 the Organic Act on the Right to Education stretched these funds to include infant education in these schools, strengthened their financial surveillance and obliged them to give a seat to local authorities in their councils.

On both occasions, those representing lighter surveillance conditions and a higher profile of Catholic values resisted the reform in the name of free education for (mostly religious) private- dependent schools whilst other groups campaigned for a stronger surveillance of these schools. Mostly, Conservative parties, Catholic Boards of Education and the Catholic Parents Association stood for the first option, and Left-wing parties and teacher unions as well as the Public Education Parents Association for the second one.

The class structure and the school sectors overlap, with middle-classes being overrepresented in private-dependent schools (Calero and Bonal, 1999; Fernández Enguita, 2008). A mid-term trend towards segregation has also been observed, in some communities noticeably exacerbated when the number of foreign-born students has escalated from 3\% to 12\% (Palaudàrias, 2002; Bonal, Rambla and Ajenjo, 2004). Although further research must still assess the segregation of middle- and workingclasses, the current situation is enough to state that school choice is connected with 
particular forms of class and ethnic intersectional inequalities (Valiente and Rambla, 2009).

How are these distributions of students configured? To start with, a class hierarchy of middle-class skilful choosers and working-class adherents to the closest educational institution has emerged in Spain like in many other countries. Several studies have already recorded this phenomenon in Andalusia, Aragon, Castilla- La Mancha, Catalonia and Madrid (Bernal, 2005; Rambla, 2006; Benito and González, 2007; Olmedo and Santa Cruz, 2008). All of them highlight the low mobilisation cost of cultural capital for the wealthier social sectors, which easily acquire sufficient knowledge of their local school system and the complementary services provided by municipalities and particular schools.

Although slightly more costly, economic and social capitals are also useful instruments for those families who avoid some particular schools and those schools who want to select their pupils (Alegre, Benito, Chela, González, 2010). Thus, the amount of tuition fees and the proportion of foreign-born students keep a significant inverse correlation (Valiente, 2009). Intake regulation is often subverted by individual exclusionary stratagems such as manipulating one's address to have children included in the desired catchment area. Often, if their initial application is not admitted in an oversubscribed school, some parents pressurise the enrolment office until an exceptional extra place is created for ad-hoc reasons (Rambla, 2006; Síndic de Greuges, 2008).

In Catalonia, both ethnographic and quantitative pieces of evidence report on how private-dependent schools negotiate admission systems so that they obtain clandestine privileges to select their own intake (Escardíbul and Villarroya, 2008, 2009). For instance, some interviews with the Inspection staff and some reports published by the Ombudsman accuse them of manipulating the requirement to reserve places for new students arriving mid-term, for informally extending the benefit of public subsidies to pre-primary courses, for privileging the children from these initial programmes by attributing them points for 'having siblings in the same school' (which are therefore not available for external students coming from cheaper nurseries), and for providing biased information on religious or economic pre-requisites to certain families during visits on open days before the enrolment period (Villarroya, 2003; Síndic de Greuges, 2008). 
Actually, all these practices were 'exceptions' to the agreements that private-dependent schools had to sign in accordance with the legislation passed in 1985, but the supporters of stricter control were not able to maintain a permanent body that monitored the effective implementation of their egalitarian requisites (Rambla, 1999). Even though they had rallied for the strict surveillance of these schools and the electoral participation of students, families and teachers in all (public and private-dependent) school councils, they could neither counteract the spread of informal exclusionary practices nor accelerate the electoral timing (e.g. the first election was delayed for some years after their campaign).

Conversely, the lobbies that defended the interests of private-dependent schools managed to influence political decisions on a piecemeal basis. Their adversaries' victory eventually allowed them to succeed, partly because they could maintain their organisation. Through ad-hoc consultation and discussion, they gained such an advantage as the label of experimental centres for the comprehensive reform implemented in the mid-nineties. The institution could provide continuity between primary and secondary education, thus calming parents worried about the transition of their 12 year old children from one school to another. Further political successes were the reforms that downplayed low income as a criterion for priority in oversubscribed schools and included infant education in the list of programmes eligible for public subsidies (Bonal, 2000; Griera, 2007).

In the end, in recent decades the interaction between middle-class parents concerned with choice and working-class parents willing to accept the closest school has reinforced categorical inequality so that most parents decide by drawing on class-related euphemisms about 'urban areas', 'school facilities', 'school climates' and 'people un/like us'. The wealthier make complex spatial and educational comparisons to choose their school, whereas many working-class families are willing to accept local schools, and thus feel threatened by any perceived sign of either degradation (e.g. delinquency, lowquality facilities) or local impoverishment (e.g. arrival of certain immigrants) (Rambla, 2006; Benito and González, 2007). In the end, the effects of family and school strategies seem to be cumulative in so far the former fashion a pattern of class-biased choice and the latter a patter of class-biased selection. 


\section{Chile: explicit but contested status}

Although the authoritarian Chilean regime established open competition between the newly created municipal schools and the private-dependent schools in the Constitutional Act on Education, since 1990 the elected authorities have increased public expenditure and implemented large-scale compensatory programmes favouring municipal schools (Almonacid, Luzón and Torres, 2008). These governments invested lots of public resources in building and improving school facilities, providing better equipment, fostering in-service teacher training and favouring the most vulnerable schools (mostly, municipal) on the grounds of positive discrimination.

However, in 1992 the government allowed private-dependent schools to complement the public subsidy with substantial contributions made by families in order to keep a place (Frías, 2009; Valenzuela, Belleï, De los Rios, 2008). Thus, recent statistical outlooks record an exacerbated polarisation of performance scores and a socioeconomic segregation of schools (Valenzuela, Belleï, De los Rios, 2008; CEPAL, 2007) in a lopsided social structure divided by a huge income gap (Hoffman and Centeno, 2003).

In 2006 secondary students launched a country-wide campaign protesting about an excessive educational selection, and particularly about the narrow access to tertiary education. This event was a watershed for public opinion, because education was widely perceived as a national endeavour and the students as the main agents of future progress. Besides, neither Left-wing parties nor unions had ever been able to launch such an initiative in the country for all the democratic period. As a response, the President convened a national commission for educational reform that partially blamed biased admission for the problem. In 2008 the Act on Preferential Subsidies was passed in order to compensate for such bias (Almonacid, Luzón and Torres, 2008; Zibas, 2008).

Unlike Spain, in Chile some working-class parents reject the hierarchy commonly established between calculative and proximity-driven choice. At least, in 2006 most middle-class respondents to our interviews assessed the pros and cons of their options, 
and most working-class families basically complied with the closest-school norm, but a number of the latter aimed at emulating strategic choice. Including agricultural labourers, industrial workers and other groups with low-skilled service jobs, this class is internally divided into those who have and those who lack a formal labour contract. Among them, the traditional preference for the closest educational institution is the rule, but surprisingly, at the time of our interviews a significant number of families had initially explored their chances in the private-dependent sector, and had finally sent their offspring to the local municipal school explicitly arguing that they could not afford the alternatives (Frias, 2009: pp. 263-8).

Therefore, the amount of private contributions has made tuition fees so costly that many popular sectors feel excluded from the private schools to which they aspire to send their children. Economic capital is the prevailing power resource in this competition, although most families are concerned with searching the most prestigious schools and many draw on their acquaintances for information and influence. Thus, in a large sample of Chilean municipalities, the index of urban segregation is associated with a more-than-proportional increase of school segregation, which is mostly due to the presence of these fee-paying, private-dependent schools in the locality. The indexes of school socio-economic segregation also reflect this exclusionary drive to the extent that high-status students score higher grades than their poorer compatriots, and privateindependent institutions have higher grades than private-dependent ones, and these than municipal institutions (Valenzuela, Belleï, De los Rios, 2008, p. 22- 25, 40-48).

Exclusionary politics are a likely cause of these distributions, not least because the owners of private schools have used their social capital for lobbying at low mobilisation and maintenance costs. At first, their comparative advantage in terms of socio-economic composition was dramatically broadened with the quasi-market reform launched in the eighties; and afterwards, the voucher system simply reinforced the self-perpetuating effect of this positional benefit (Torche, 2005; Hsieh and Urquiola, 2006; Matear, 2007). Later on, private and private-dependent schools easily managed to select the best students via tuition fees and explicit marketing strategies. Eventually, their bettertrained and better-paid managers became much more able to foresee possible opportunities coming from innovative programmes, to multiply their subsidies by artificially stretching the list of generously supported students with 'language-related 
special education needs', and to reduce costs by diverting troublesome students towards neighbouring municipal schools (Frias, 2009; Almonacid, Luzón, Torres, 2008). What is more, in the early nineties the coalition of these owners gained the liberalisation of private contributions in spite of important opposition from within the Concertación de Partidos por la Democracia -that is, the alliance of political parties backing the presidents, comprising the Demo-Christian, Socialist, Radical and Democracy Parties(Colegio de Profesores, 2005; Valenzuela, Belleï, De los Rios, 2008; Zibas, 2008).

Here, school choice is rooted in categorical inequality too; essentially, in classifications which make reference to class and ethnic divides. Our evidence underpins some claims of class implications, but we lack data on the categories into which Mapuche- and Aymara- speaking minorities (and maybe Peruvian immigrants) were probably placed. As regards class, most parents have stated in public opinion surveys that their offspring would rather attend socially uniform educational institutions, whereas in other countries like the US these surveys yield high percentages of parents preferring socially mixed schools for their children (Valenzuela, Belleï, De los Rios, 2008, p. 9).

School selection also exacerbates this class pattern, mostly due to the uneven resources of private and municipal schools. Additionally, one of the schools sampled for our fieldwork also happened to provide supplementary evidence of the constrained margin of municipal schools. Actually, it was the only oversubscribed municipal school that had managed to concentrate a relatively homogeneous intake of working-class parents with a formal labour contract and achieved a somewhat good average performance. But the principal and the teachers realised that this small positional advantage nevertheless provided insufficient help for their students to achieve either post-compulsory education or future labour opportunities. Other non-educational hindrances of social mobility were so strong that academic improvement alone was too weak a counterbalance for those students with such a lower social background in that 'lopsided' society (Frías, 2009). 


\section{Path-dependent connections between choice and segregation}

Table 2 estimates the school segregation (as dissimilarity) of students with a low socioeconomic status in a number of OECD countries including Spain and Chile. The Dissimilarity Index (D) measures the number of students who would have to move from one school to another if those with a lower social, economic and cultural status were to be distributed on an even basis (Duncan and Duncan, 1955). The value of D ranges from 0 to 1 ; with 0 being the situation of perfect equality (no segregation) and 1 the situation of perfect inequality (maximum segregation). The general pattern is that this share is larger in education systems where 15 year olds are divided into different academic and vocational paths. For instance, four out of ten students would move in Slovenia (where almost half of them are enrolled in purely vocational paths) whereas only three out of ten would move in Denmark (where nobody is enrolled in a purely vocational path). The table highlights that segregation is significantly higher in Spain and Chile when compared to other countries where nobody is enrolled at fifteen in a programme that gives access to vocational studies at the next programme level or direct access to the labour market.

By comparing Table 2 and Table 1, it may be suggested that in some countries segregation and a great presence of private-dependent institutions coincide. However, this is a very slight trend with many exceptions: thus, the score of $\mathrm{D}$ is quite analogous in the Slovak Republic, Spain and the US in spite of disparate proportions of students in these schools; furthermore, Chile records the most exacerbated segregation but has a lower proportion of students in private-dependent schools than Belgium. 
Table 2: Segregation of students with a low social, economic and cultural status (ESCS) in several OECD countries. 2006

\author{
Number of school types \\ Dissimilarity \\ Index
}

Proportion of 15 year olds enrolled in programmes that provide access to vocational studies at the next programme level or direct access to the labour market

$\begin{array}{cccc}\text { Chile } & 0.53 & 2 & 0 \\ \text { Hungary } & 0.49 & 3 & 17.8 \\ \text { France } & 0.42 & \mathrm{w} & \mathrm{w} \\ \text { Greece } & 0.42 & 2 & 13.7 \\ \text { Slovenia } & 0.41 & 3 & 52.1 \\ \text { Portugal } & 0.41 & 3 & 14 \\ \text { Germany } & 0.40 & 4 & \mathrm{w} \\ \text { Belgium } & 0.40 & 4 & 22.4 \\ \text { Italy } & 0.40 & 3 & 2.2 \\ \text { Lithuania } & 0.40 & 3 & 0.2 \\ \text { Austria } & 039 & 4 & 41.5 \\ \text { Slovak Rep } & 0.39 & 5 & 10.8 \\ \text { Spain } & 0.39 & 1 & 0 \\ \text { USA } & 0.39 & 1 & 0 \\ \text { Korea } & 0.38 & 3 & 23.2 \\ \text { Poland } & 0.38 & 1 & \mathrm{~m} \\ \text { Latvia } & 0.37 & 3 & 3.4 \\ \text { Czech Rep } & 0.37 & 5 & 15.6 \\ \text { Netherlands } & 0.36 & 4 & 54.7 \\ \text { Switzerland } & 0.36 & 4 & 6.2 \\ \text { Estonia } & 0.35 & 1 & 1.8 \\ \text { Canada } & 0.34 & 1 & 0 \\ \text { UK } & 0.34 & 1 & 0 \\ \text { Hong Kong } & 0.33 & 3 & 0 \\ \text { Ireland } & 0.32 & 4 & 0 \\ \text { Denmark } & 0.29 & 1 & 0 \\ \text { Sweden } & 0.29 & 1 & \\ \text { Finland } & 0.25 & & \\ \text { Source: OECD } & 2007) & & 0 \\ & & 1 & \end{array}$

This comparative account of school segregation is quite helpful to review and interpret the former qualitative findings on the politics of school choice in Spain and Chile ${ }^{2}$. In

\footnotetext{
2 A further comment might clarify the value of this comparative statement. Both Rambla (2006) and Frías (2009) report on similar semi-focused interviews with parents in Spain and Chile, but it is only in Chile that some working-class interviewees were quite explicit about their adaptation to the cost of private-dependent schools. This unexpected finding is the basis of our comparative account, and certainly a source of many more research questions. In our view, there is enough evidence to argue that this strategy has not been so visible in Spain so far: although for the last decade parental choice strategies have been analysed on the grounds of interviews (Bernal, 2005; Rambla, 2006; Olmedo and Santa Cruz, 2008) and focus groups (Rambla, 2006; Benito and González, 2007), this adaptation of preferences has
} 
most countries the interplay of choice strategies eventually distributes students between schools according to the economic, social and cultural capitals of families; but significantly, in Chile some lower-class parents report having changed their minds because they cannot afford the tuition fees of the schools they desire, and school intakes are polarised despite a very slight concept of tracking (Frías, 2009). Interestingly, current legal arrangements allow both private and private-dependent schools to charge a significant fee; and simultaneously, parental reactions not only include middle-class skilful decision-making and working-class adherence to the proximity norm, but also adaptive preferences with regards to costly desired options. The outcome is that half of the student population would be transferred from one school to another if all the schools were to have an analogous social composition.

In Spain, a more restrictive regulation and a different combination of strategies produce a not so polarised but also segregative outcome. Although on a very controlled scale, private-dependent schools are also allowed to charge some tuition fees that middle-class families pay in exchange for a more select school intake (Valiente, 2009). Here, notable is the fact that middle-class families not only get better information about the characteristics of local schools, but they often deploy an array of stratagems in order to meet their preferences (Rambla, 2006; Benito and González, 2007). As a consequence, the school allocation of four out of ten 15 year olds disrupts a hypothetically common ground of mixed distribution.

In both countries the regulation of public and private-dependent sectors raises a political cleavage. At an individual level, some parents draw on different power resources to have their offspring enrolled in certain schools; at the same time, unions and lobbies struggle and bargain to either tame selective admission or gain advantage through institutional loopholes. In Spain and Chile, although governments have tightened regulation, private-dependent schools have availed of ad-hoc opportunities such as experiencing pedagogic innovation (in Spain in the 1990s) and the diagnosis of some special education needs (in Chile in the 2000s). These advantages are quite significant insofar as they are not supposed to be legitimate according to the principles of democratic transitions. Moreover, some social movements have periodically 
campaigned against them and have exerted an important influence on regulatory reforms. However, while the foundations and institutions that run private-dependent schools and their political lobbies can afford the maintenance costs of their activities, the organisers of these campaigns face more difficulties to mobilise parents and educators and lack the organisation and funding to maintain permanent offices that monitor the effective implementation of the general principle in all the specific decisions that all the competent authorities make each academic year in all the areas of education policy (Korpi, 1985). As a consequence, such imbalance produces a sort of 'ratchet effect' (Ball, 2008) consisting in these countries of long-term, established privileges for private-dependent schools. This effect is produced by the complex interaction between individual strategies deployed in the arena of school choice, and the outcome of political interplay. The use of social, economic and cultural capitals reveals that individuals develop their own interest within the constraints and opportunities posited by the social structure in each country. At the same time, the relevance of collective action, albeit episodic, reveals key struggles whereby cultural frames are challenged and current institutions contested.

Class composition and school types intermingle with categorical inequality in both countries too. In interviews, the salient colloquial categories are not constrained to educational characteristics such as achievement or special needs but address social classes and ethnic groups through many references to 'urban areas', 'school climates' and 'people un/like us' (Benito and González, 2007; Frías, 2009). Eventually, while 'choice of the upward mobile parents' divides school institutions in some education systems (in Austria, Ireland, Czech Republic, Finland, Denmark, Germany, Sweden, Switzerland and Hong-Kong pupils coming from families with more cultural possessions and a less educated mother who nevertheless has a high-level occupation concentrate in privatedependent schools), it is 'segregation by lower middle-class parents' that sets the pattern in Spain and Chile. Like in Belgium, the Netherlands, Portugal, Thailand, Hungary, Slovakia, Israel, Italy and Korea, in our two case studies the intake of private dependent-schools includes more pupils with less cultural possessions at home, and a more educated mother with an average-status occupation (Dronkers and Avram, 2009). The quantitative relevance of the latter strategy suggests that large private-dependent sectors may convey this defensive strategy in some countries like the ones we focus on. 


\section{Conclusion}

School choice contributes to socio-economic segregation insofar as some schools that compete for students manage to establish their own admission filters (West et al, 2004; Fuchs and Wößmann, 2006; Alegre and Ferrer, 2009). Spain and Chile replicate this general pattern insofar as tuition fees divide two large sectors of public and privatedependent schools in the two countries. Like elsewhere, social and cultural capitals clearly help middle-class families to elaborate sophisticated strategies of school choice, but in the end they draw on their economic capital to pay for a selective school that is subsidised at the same time as allowed to charge a fee. In Chile we find an exacerbated case of selective choice to the extent that, unlike the majority of acknowledged case studies, here some lower-class families do not comply with the social norm of accepting the closest public school but only accept it after realising that alternatives are unaffordable for them.

Significantly, in the two countries the political representatives of private-dependent schools have been very successful at lobbying in pursuit of their interests, although their political adversaries who favour a stricter regulation of these schools have won some notorious victories. In fact, the former appear to avail of uneven power resources, since they easily maintain their regular activities in representation and pressure whereas their opponents can only mobilise their support in particular conjunctures, and cannot maintain effective agents of influence and monitoring afterwards.

In line with Pawson (2006) we emphasise a crucial connection between sociology and policy studies in the analysis of school choice. In this author's view, programme designs (e.g., quasi-markets, controlled choice schemes and regulated large private-dependent sectors) do not yield automatic impacts but different, complex and non-mechanical effects due to the diverse understanding, interests, strategies and power resources of the involved stakeholders. Our conclusion highlights that institutional designs are implemented by agents who impinge on their circumstances availing of structural and cultural resources. These agents can also intervene to challenge current conditions and think of alternatives (Wright, 2006). The Spanish and the Chilean cases reveal that admission fees are likely to polarise school intakes due to both differential strategies and intended closure; furthermore, political equilibria eventually underpin these 
exclusionary practices in both countries, sometimes despite the logic of current institutional designs.

\section{References}

Aguste, S. and Valenzuela, JP.. 2006. Is It Just Cream Skimming? School Vouchers in Chile. mimeo.

Alegre, M. A., Ferrer, G., 2009. School regimes and education equity:some insights based on PISA 2006. British Educational Research Journal iFirst Article: 1-29.

Alegre, M.A., Benito, R., Chela, X., \& González, I. 2010. Disposicions, estratègies $i$ pràctiques d'elecció escolarDesigualtats en la tria de centre a la ciutat de Barcelona. Barcelona: IGOP- UAB- FJ Bofill.

Almonacid, C., Luzón, A., and Torres, M. 2008. Cuasi mercado educacional en Chile: el discurso de los tomadores de decisión. Archivos Analíticos de Políticas Educativas 16, no. 8: 1-41.

Archer, M. 2000. Being Human. The Problem of Agency. Cambridge: Cambridge University Press.

Ball, S., and Gewirtz, Sh. 1995. Markets, Choice and Equity in Education. Milton Keynes: Open University Press.

Ball, S.J. 1997. On the cusp: parents choosing between state and private schools in the UK: action within an economy of symbolic goods. International Journal of Inclusive Education 1, no. 1: 1-17. . 2008. The Legacy of ERA, Privatization and the Policy Ratchet. Educational Management, Administration and Leadership 36, no. 2: 185-199.

Ball, S.J., and Vincent, C. 1998. 'I Heard It on the Grapevine': 'hot' knowledge and school choice. British Journal of Sociology of Education 19, no. 3: 377 - 400.

Benabou, R., Kramarz, F., and Prost, C. 2005. The French Zones d'Édication Prioritaire: Much Ado About Nothing? Centre for Economic Policy Research Discussion Papers 5085: 1-39.

Benito, R., and González, I. 2007. Processos de segregació escolar a Catalunya. Barcelona: Fundació Jaume Bofill.

Bernal, J. L., 2005. Parental choice, social class and market forces: the consequences of privatization of public services in education. Journal of Education Policy 20, no. 6: $779-792$.

Bonal, X. 2000. Interest groups and the state in contemporary Spanish education policy. Journal of Education Policy 15, no. 2: 201-216.

Bonal, X. 2002. Plus ça change... The World Bank Education Policy and the PostWashington Consensus. International Studies in Sociology of Education 12, no. 1: $3-21$.

Bonal, X., Rambla, X., and Ajenjo, M. 2004. Les desigualtats territorials en l'ensenyament a Catalunya. Barcelona: Editorial Mediterrània.

Boulton, P., and Coldron, J. 1996. Does the rhetoric work? Parental responses to New Right policy assumptions. British Journal of Educational Studies 44: 296-306.

Bourdieu, P. 1986. Three forms of capital. In Handbook of Sociological Theory, 241258. New York: Greenwood Press.

Butler, T. 2007. EDITORIAL School Choice: a European Perspective. Journal of Education Policy 22, no. 1: 1-5. 
Calero, J. 2007. Evaluación de servicios educativos: el rendimiento en centros públicos y privados medido en PISA-2003. Hacienda Pública Española 183, no. 4: 3366.

Calero, J., and Bonal, X. 1999. Política educativa y gasto público en educación. Aspectos teóricos y una aplicación al caso español. Barcelona: PomaresCorredor.

CEPAL. 2007. Calidad de la educación: las desigualdades más allá del acceso y la progresión educativa. In Panorama Social de América Latina. CEPAL. Santiago de Chile: CEPAL.

Colegio de Profesores de Chile. 2005. Informe Nacional Chile. In Reformas educativas en los países del Cono Sur. OLPEd. Buenos Aires: CLACSO.

Crozier, G., D. Reay, James, D., Jamieson, A., Baedell, Ph., Holllingworth, S., and Williams, K. 2008. White middle-class parents, identities, educational choice and the urban comprehensive school: dilemmas, ambivalence and moral ambiguity. British Journal of Sociology of Education 29, no. 3: 261-272.

Dale, R. 2005. Globalisation, knowledge economy and comparative education. Comparative Education 41, no. 2: 117-149.

Dronkers, J, and Avram, S. 2009. A Cross-national Analysis of the Relations between School Choice and Effectiveness Differences between Private-Dependent and Public Schools. Zeitschrift für Pädagogik, no. 55: 895-909.

Dupriez, V., Dumay, X., and Vause, A.M. 2008. How Do School Systems Manage Pupils' Heterogeneity? Comparative Education Review 52, no. 2: 245-273.

Edwards,T., Fitz, J., and Whitty, G. 1989. The State and Private Education. An evaluation of the Assisted Places Scheme. Lewes: Falmer Press.

Elacqua, G., Schneider, M., Buckley, J. 2006. School Choice in Chile: Is It Class or the Classroom? Journal of Policy Analysis and Management.

Elias, N. 1983. Power and Civility. The Civilising Process (vol 2). New York: Pantheon Books.

Escardíbul, O., and Villarroya. 2009. The inequalities in school choice in Spain in accordance to PISA data. Journal of Education Policy 24, no. 6: 673 - 696.

Escardíbul, O., and Villarroya, A. 2008. Políticas públicas y posibilidades efectivas de elección de centro en la enseñanza no universitaria en España. Profesorado. Revista de Currículum y de Formación del Profesorado 12, no. 2: 1-24.

Felouzis, G. 2009. School Markets. In RAPPE International Seminar. Univ Geneve.

Felouzis, G., Liot, G., and Perroton, L. 2005. L'apartheid scolaire. Enquête sur la ségrégation ethnique dans les collèges. Paris: Éditions du Seuil.

Fernández Enguita, M. 2008. Escuela pública y privada en España: la segregación rampante. Profesorado. Revista de Currículum y de Formación del Profesorado 12, no. 2: 1-28.

Filgueira, F., and Bogliaccini, J. A. 2004. Las reformas educativas en Chile y Uruguay. In Descentralización y políticas sociales en América Latina, 297-348. Jordana, J, Gomà, R. Barcelona: CIDOB.

Fletcher- Campbell, F., Whitby, Karen, White, K., and Chamberlain, T. 2007. Review of International Literature on Admissions. London: National Foundation for Educational Research.

Frías, C. 2009. Familia y elección escolar en el mercado educativo local. Thesis in Sociology. Univ Autònoma de BarcelonaEditor, forthcoming.

Fuchs, Th., Wößmann, L. 2007. What accounts for international differences in student performance? A re-examination using PISA data. Empirical Economics 32: 433-464. 
García Huidobro, J.E. 2006a. La reforma educacional chilena y la educación pública. In Globalización, educación y pobreza en América Latina. ¿Hacia una nueva agenda política?, 187-218. Barcelona: Fundació CIDOB.

. 2006b. La subvención escolar preferencial: ¿remedio para la equidad? Revista Mensaje Marzo- Abril: 1-6.

2007. ¿Qué nos dicen las movilizaciones estudiantiles del 2006 de la visión de los estudiantes sobre la educación secundaria? In Seminario sobre Docentes y Estudiantes de Educación Secundaria. Buenos Aires: Fundación Santillana.

Glenn, C.L. 1989. Choice of School in Six Nations: France, Netherlands, Belgium, Britain, Canada, West Germany. Washington D.C.: Office of Educational Research and Improvement.

Griera, M. M. 2007. The Education Battle. The Role of the Catholic Church in the Spanish Education System. In International Handbook of Catholic Education, 291-310. Gerald Grace and J O'Keele. Dordrecht (NL): Springer.

Hatton, E. 1985. Equality, Class and Power. British Journal of Sociology of Education 6: $255-272$.

Hoffman, K., and Centeno, M.A. 2003. The Lopsided Continent: Inequality in Latin America. Annual Review of Sociology 29: 363-90.

Hsieh, C., and Urquiola, M. 2006. The effects of generalized school choice on achievement and stratification: Evidence from Chile's voucher program. Journal of Public Economics 90: 1477 - 1503.

Jessop, B. 2007. State Power: A Strategic-Relational Approach. London: Polity.

Korpi, W. 1985. Resources Approach vs. Action and Conflict: On Causal and Intentional Explanations in the Study of Power. Sociological Theory 3, no. 2: $31-45$.

Korpi, W. 2001. Contetious Institutions: An Augmented Rational- Action Analysis of the Origins and Path Dependency of Welfare State Institutions in Western Countries. Rationality and Society 13, no. 2: 235-283.

Lareau, A. 1995. Gender Differences in Parental Involvement in Schooling. In Education and Gender Equality, 207-225. Wrigley. J. London: The Falmer Press.

Lukes, S. 2005. Power. A Radical View. Hampshire (UK): Palgrave Macmillan.

Maroy, C. (dir). 2006. École, régulation et marché: une comparaison de six espaces scolaires locaux en Europe. Paris: Presses Universitaires de France.

Maroy, C. 2004. Regulation and Inequalities in European Education Systems. Changes in regulation modes and social production of inequalities in education systems: a European Comparison Contract $n^{\circ}$ : HPSE-CT2001-00086 . Project $n^{\circ}$ : SERD2000-00069.

Maroy, C., and Demailly, L. 2004. Les régulations intermédiaires des systèmes éducatifs en Europe: quelles convergences? Recherches Sociologiques XXXV, no. 2.

Matear, A. 2007. Equity in education in Chile: The tensions between policy and practice. International Journal of Educational Development 27: 101-113.

Maurin, É. 2004. Le ghetto français. Enquête sur le séparatisme social. Paris: La République des Idées et Seuil.

Narodowski, M., and Nores, A. 2002. Socio-economic Segregation with (without) Competitive Education Policies. A Comparative Analysis of Argentina and Chile. Comparative Education 38, no. 4: 429-451.

OECD. 2007. PISA 2006: Science Competencies for Tomorrow's World. Paris: OECD. 2010. Statistics. 
Olmedo, A., and Santa Cruz, J. 2008. Las familias de clase media y elección de centro: el orden instrumental como condición necesaria pero no suficiente1.

Profesorado. Revista de Currículum y de Formación del Profesorado 12, no. 2: $1-30$.

Palaudàrias, J.M. 2002. Escola i immigració estrangera a Catalunya: la integració escolar. Papers. Revista de Sociologia, no. 66: 199-213.

Poupeau, F., François, J.-Ch., and Couratier, E. 2007. Making the right move: how families are using transfers to adapt to socio-spatial differentiation of schools in the greater Paris region. Journal of Education Policy 22, no. 1: 31 - 47.

Rambla, X. 1999. La participación ciudadana en la escuela. Revista Internacional de Sociología 24 (sept- dic): 55-73.

2006. L'alchimie des aspirations educatives: la confiance dans les mérites scolaires en Espagne. Régards Sociologiques, no. 31: 17-34.

Raveaud, M., and Van Zanten, A. 2007. Choosing the local school: middle class parents' values and social and ethnic mix in London and Paris. Journal of Education Policy 22, no. 1: 107-124.

Reay, D., and Ball, S.J. 1997. 'Spoilt for Choice': the working classes and educational markets. Oxford Review of Education 23, no. 1: $89-101$.

Rizvi, F., and Lingard, B. 2006. Globalization and the changing nature of the OECD's educational work. In Education, globalization \& social change, 247-260. Lauder, H, Brown, P, Dillabough, J., Halsey, H. Oxford UK: Oxford University Press.

Robertson, S. 2005. Re-imagining and rescripting the future of education: global knowledge economy discourses and the challenge to education systems. Comparative Education 41, no. 2: 151-170.

Síndic de Greuges. 2007. Informe Extraordinari: La Segregació Escolar a Catalunya. Barcelona: Síndic- Parlament de Catalunya.

Swift, Adam. 2004. The Morality of School Choice. Theory and Research in Education 2, no. 1: 7-21.

Tarrow, S. 1998. El poder en movimiento [Power in Movement]. Madrid [Cambridge]: Alianza Editorial.

Therborn, Goran. 2006. Inequalities of the World. London: Verso.

Thrupp, Martin. 2007. School Admissions and the Segregation of School Intakes in New Zealand Cities. Urban Studies 44: 1393-1404.

Tilly, C. 1998. Durable Inequalities. Berkeley: University of California Press.

Tomasevski, K. 2006. The State of the Right to Education Worldwide: Free or Fee. Paris.

Torche, F. 2005. Privatization Reform and Equality of Educational Opportunity in Chile. Sociology of Education 78, no. 4: 316-343.

Torche, Florencia. 2005. Privatization Reform and Inequality of Educational Opportunity: The Case of Chile. Sociology of Education.

UNESCO Institute for Statistics. 2009. Education Data.

Valenzuela, J.P., Belleï, C., and De los Rios, D. 2008. Evolución de la segregación socioeconómica de los estudiantes chilenos y su relación con el financiamiento compartido. Santiago de Chile.

Valiente, O. 2009. Elecció de centre i segregació escolar a Catalunya. Cerdanyola del Vallès: Universitat Autònoma de Barcelona.

Valiente, O., and Rambla, X. 2009. The New Other Catalans at school: decreasing unevenness but increasing isolation. International Studies in Sociology of Education 19, no. 2: 105 - 117. 
Van Zanten, A. 2003. Middle-class Parents and Social Mix in French Urban Schools: reproduction and transformation of class relations in education. International Studies in Sociology of Education 13, no. 2: 107-124.

Van Zanten, A. 2002. Educational change and new cleavages between head teachers, teachers and parents: global and local perspectives on the French case. Journal of Education Policy 17, no. 3: 289 - 304.

Villarroya, A. 2003. La financiación pública de la enseñanza privada no universitaria en España. Revista de educación 330: 187-204.

Vincent, C., Vincent, C., Ball, S.J., and Braun, A. 2008. It's like saying 'coloured': understanding and analysing the urban working classes. Sociological Review 56, no. 1: 61-77.

West, A., Hind, A. and Pennell, H. 2004. School admissions and 'selection' in comprehensive schools:policy and practice. Oxford Review of Education 30, no. 3: $347-369$.

Wright, E.O. 2006. Compass Points. Towards a Socialist Alternative. New Left Review 41: 93-124.

Zibas, D. M.L. 2008. 'A Revolta dos Pingüins' e o novo pacto educacional chileno. Revista Brasileira de Educação, 13, no. 38: 199-220. 